Please cite this post-print as:

Emrani, E., Moradi-Salari, A. and Jamali, H. R. (2010), "Usage data, e-journal selection and negotiations: Iranian consortium experience", Serials Review, 36 (2), 86-92.

DOI: $10.1016 /$ j.serrev.2010.03.004

Published version: http://dx.doi.org/10.1016/j.serrev.2010.03.004

\title{
Usage Data, e-journal selection, and Negotiations: Iranian Consortium experience
}

\author{
Ebrahim Emrani \\ Head Librarian \\ Address: Faculty of Sciences, University of Tehran, Enghelab Ave, P.O.Box: 14155- \\ 6455 \\ Email: emrani@khayam.ut.ac.ir \\ Phone: +98 2166495290 \\ Amin Moradi-Salari \\ Director of Scientific Information Department, Central Acquisition Office \\ Address: University of Tehran, Enghelab Ave, P.O.Box: 14155-6455 \\ Email: salari@ut.ac.ir \\ Phone: +982166493114
}

\section{Hamid R. Jamali}

Assistant Professor, $\mathrm{PhD}$

Address: Department of Library and Information Studies, Faculty of Psychology and Education, Tarbiat Moallem University, No 49, Mofateh Ave, P.O.Box: 15614,

Tehran, Iran

Email: h.jamali@gmail.com

\begin{abstract}
This article reports on the analysis of COUNTER-compliant usage data of Elsevier ScienceDirect journals by an Iranian national consortium, Consiran (58 institutions) for the period of 2004-2009. The aim of the analysis was to develop a license model. The results showed that the use followed the " $80 / 20$ rule" or Pareto principle. It was concluded that for a cost-benefit license model, institutions should be grouped into three or four categories based on their subject fields and amount of use. The article also discusses the problem with usage data and highlights the need for implementing a system to locally collect and analyse usage data, rather than relying on the usage data provided by vendors and publishers.
\end{abstract}


Keyword: Usage analysis, Iran, Consiran, ScienceDirect, periodicals, journal selection, negotiations

\section{Introduction}

The transition from print to e-resources resulted in a paradigm shift in how libraries acquire and manage information resources ${ }^{1}$. One of the effects of this shift was the emergence of journal licensing. The history of licensing work within libraries goes back to the 1990s when e-journals appeared. The difference in the case of e-journals, compared to print journals, is that libraries do not own or control access to the content and this shift in control over access to content is still at the heart of licensing negotiation today ${ }^{2}$. Now many universities purchase their journals from large publishers in the form of bundled site licenses that give them electronic access to nearly a publisher's entire subscription list at a price that depends on their historical expenditures on print journals from that publisher. Frazier, named this system the 'Big Deal'. ${ }^{3}$

In order to have better negotiation ability and gain more benefits, libraries started to work together and form consortia. Some of these consortia work at a national scale. The examples are Canadian National Site Licensing Project (CNSLP), The National Electronic Site License Initiative (NESLI) in UK, and South African Site License Initiative (SASLI). According to Turner a national site license "can provide a single license that is operative across the content of many publishers, have the support of the appropriate national body, and all of the nation's higher education institutions are subscribed"4.

\section{Problem statement}

Iran has a large network of private, public, and state affiliated universities. State-run universities are divided into two groups. Those that offer degrees in medical sciences are under the direct supervision of the Ministry of Health and Medical Education and the rest (non-medical universities) are run by the Ministry of Science, Research and Technology (MSRT). There is also a large private university, Islamic Azad University, which has numerous branches across the country. In 2008, Iran had over 3.5 million students enrolled in universities.

Consiran is the Iranian academic library consortium which is supervised by MSRT and covers 83 universities and research centers. Although, Consiran is affiliated to MSRT, there have been several requests by other universities and institutes for joining the consortium and we are hopeful to be able to accept non-MSRT members in the future. The consortium is responsible for making serial deals with different publishers. Collective purchase of journals in the form of buying club has been popular in Iran since 1989, especially among the MSRT universities. After ten years of experience, at the end of 1990s the situation forced us to from some sort of consortium for buying online databases. The same consortium was also used for buying e-journals. Elsevier is one of the main publishers and about $50 \%$ of the money Iranian universities spend on e-journals is spent on ScienceDirect journals. The largest deals so far have also been related to Elsevier journals with 58 members participating in the purchase. In the deal that we made with Elsevier for the three-year period of 2004-2006, 23 members of Consiran participated and they could access all of non-medical ScienceDirect journals (1396 titles at the time). 
Elsevier offered us a special discount for this period so the universities could gradually adjust their budgets with the increasing prices. The discount rate was $70 \%$ of licence agreement for $2004,50 \%$ for 2005 and $30 \%$ for 2006 . When we started to think about the deal for the next three-year period (2007-2009), we faced a few problems:

1. The number of members increased from 23 to 58 universities and research centers. The demand for the journals increased while many of these institutions did not have enough budget for the purchase of e-journals and they were hopeful of receiving monetary help from other institutions or MSRT.

2. Elsevier made it clear that it would not offer any discount for 2007-09 period.

3. We did not have any information about how cost-benefit the previous deal was and how the journals had been used by the members.

Elsevier had a few solutions or models for the deals including:

1. Full access to the whole collection for all members: the lack of budget forced us to rule out this option.

2. Access to specific collections: for example chemistry collection or management collection. This type of deal could not reduce the cost because Iranian large universities needed journals from a wide range of subjects, and there were only a few specialised research centres that needed journals from one or a few subjects. Therefore, they had to spend more money on journals in this type of deal. We might think that this would have been better for the research centres but given the budget limitations this was not possible for all centres.

3. Access to a certain number of journals, which is called Unique Title List (UTL): in this model, universities could choose some journals and have access to a certain number of journals based on the publisher price list. Those universities that had perpetual right had to maintain their subscription.

In order to decide about the deal for 2007-09 period, we started to analyse the usage data of Elsevier journals.

Knowing the cost of journals and the amount of use of each title by institutions is necessary for negotiating with publishers and making the right deal. Collecting and analyzing usage data for e-journals is now a well-discussed method that consortia use to make the right collection building decisions. Standardization of usage data by projects such as COUNTER has facilitated the analysis of usage data. In this article we report on the analysis of usage data of Elsevier journals by an Iranian national consortium, Consiran, which has been done for developing a license model.

\section{Literature review}

The importance of usage data for making collection building decisions has increased in recent years due to a number of factors such as the international initiatives for standardization of the usage reports, availability of the data and the increase in the number of available digital resources. Usage data analysis has gained more important since the introduction of what is known as the big deal.

Different methods have been used for the collection assessment and use of e-journals including citation analysis ${ }^{5}, \log$ analysis $^{6}$ and analysis of usage statistics ${ }^{7}$.

Tonta \& Ünal ${ }^{8}$ analyzed consortial use of Elsevier journals in Turkey (ANKOS consortium) for the period 2001 to 2007 to develop better consortial collection management policies and empower the consortium management to negotiate better deals with publishers. Their study showed a total of 25 million full-text article downloads. Some 100 core journals, constituted only 5\% of all ScienceDirect journal 
titles and accounted for over 8.4 million download requests. A large number of journal titles were rarely used while some were never used at all. They claimed that removing $30 \%$ of journal titles from the tail, i.e. journals with little usage, would have almost no effect on consortial core journal list of ANKOS. They also maintained that individual ANKOS members could function perfectly well without those titles and their download requests for a small number of disenfranchised journal titles could be satisfied by other means (e.g. pay-per-view).

Gatten and Sanville ${ }^{9}$ analyzed the download data to identify the use patterns of journal titles within OhioLINK consortium. They showed that an orderly retreat (i.e., title-bytitle elimination of rarely used titles) "based on the ranking of articles-downloaded aggregated across member institutions appears to be a reasonable method to employ if needed...An effective orderly retreat means consortia have the ability to manage a Big Deal based on a 'cost for content' approach."

A study ${ }^{10}$ was conducted on the use of e-journals in 68 French universities that were members of Couperin consortium. The results showed that from 2001 to 2005, the requests for full text articles offered by the eight publishers mentioned above increased rapidly from around three million to more than 13 million. The full text article requests per user increased between 2003 and 2005 from 19 to $41(+116 \%)$. The average cost per full text article request in 2005 was $€ 1.60$, that was about $20 \%$ above the observed average cost in the UK or USA.

\section{Methods}

We obtained COUNTER-compliant usage reports of Elsevier journals for all of the members of Consiran. The titles did not include medical sciences titles. Usage data for the years 2004 to 2008 were aggregated and analysed using Excel.

\section{Findings}

\section{Usage data for the period 2004-2006}

First, we calculated the price of 1,394 journals to which we had access in the period 2004-2006. But the price still was too high even for many of the large and medium sized universities and as the usage statistics revealed, the use of many journals in the list was close to zero ( 0 to 3 downloads for $50 \%$ of the journals). Therefore, we decided to analyse the use by the whole consortium.

We analysed only the usage for the years 2005 and 2006 and ignored 2004 as some of the members joined the consortium after 2004 and some others had difficulties accessing the journals during this year due to network and facility problems. We also tested the " $80 / 20$ rule", or Pareto principle ${ }^{11}$, which indicates that 80 percent of the usage by all members coming from 20 percent of the titles. The analysis of 80 percent of use in 2005-06 showed that the total number of article downloads was 4,900,521, and that 429 titles (26.67\% of collection) accounted for $80 \%$ of use (see figure 1)

Figure 1. Use of UTL1 collection in 2005-06 


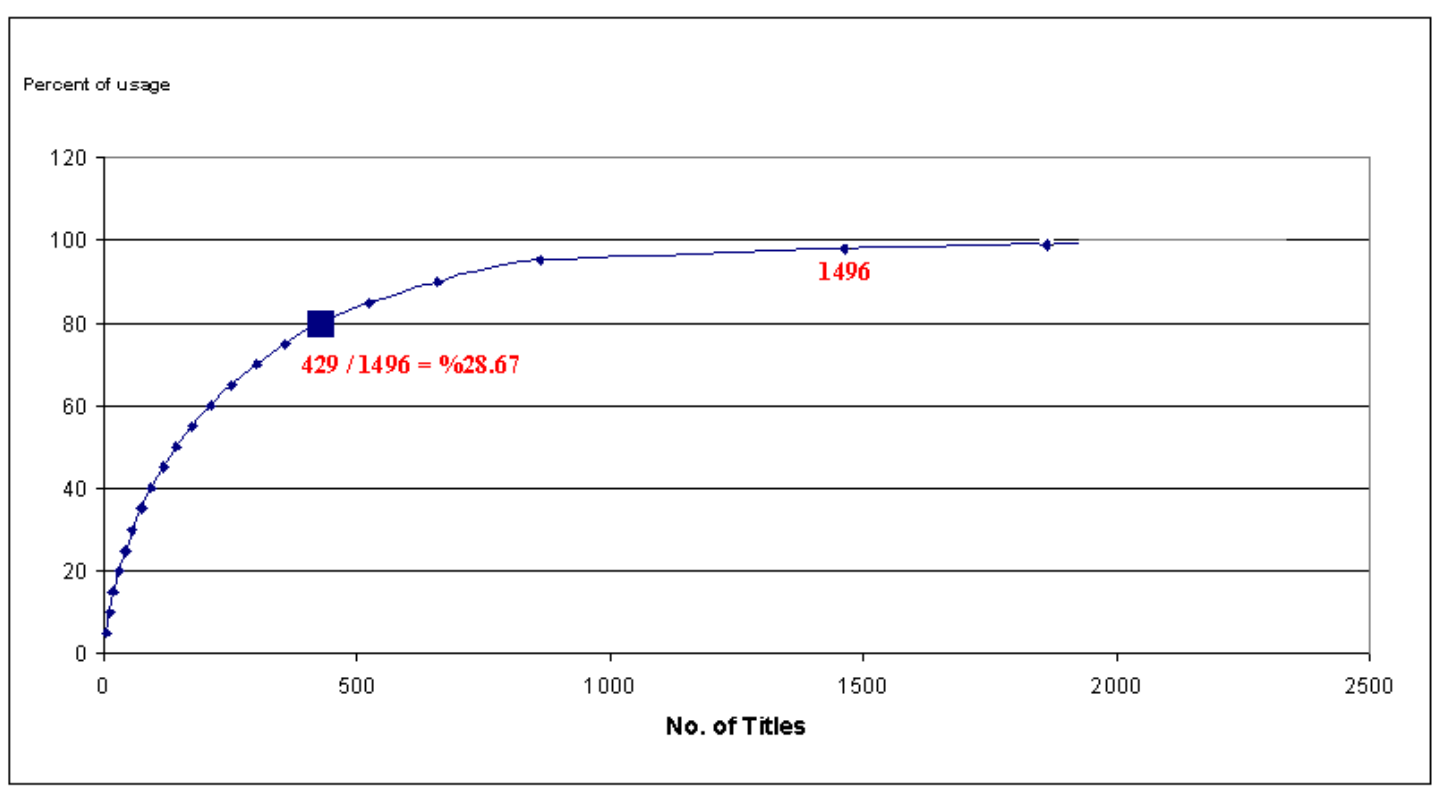

At this stage we analysed the list of 429 titles. To have confidence on the accuracy of publisher's statistics, we compared them with the statistics of photocopies of print journals in two faculty libraries of the University of Tehran (a large university with high level usage). We found $88 \%$ similarity between downloads and photocopies (i.e. hard-copy use). For example if the largest amount of photocopying belonged to Tetrahedron, the journal was also the second most used title in the publisher's download statistics.

From the 429 titles, 137 were available in print format in the Faculty of Sciences at the University of Tehran. Photocopy statistics for 121 titles were similar to download data. Sixteen titles showed considerable differences between their photocopy and download statistics. It should be said that the accurate estimation was not possible and the 12 percent different could be due to problems associated with download data (see discussion section).

The next step was preparing a list of the required journals to give to the publisher and start negotiating. However, taking a closer look at the journals list we noticed that we were about to make a big mistake. A considerable number of titles that had been used by researchers and academics for many years and their print version were available in the libraries, were not included in the list. So the question was: "was the 80 percent of use really 80 percent of use by researchers?"

The answer was no. The usage statistics for larger universities overshadowed the usage data for smaller universities. Therefore, the list of journals that accounted for 80 percent of use by larger universities would be very different from that of smaller universities or research centres. The University of Tehran with 11,500 postgraduate students and 2,200 faculty members, Sharif University of Technology and Tarbiat Modarres University could impose their list to all other universities. A journal that is used heavily at the University of Tehran could be of no use in a specialised research centre. Therefore, we decided to prepare an 80 percent of use list by each university (Table 1). The cumulative list then included 6,099 titles which reduced to 647 titles after eliminating the repeated titles. This list then was used as the basis for the later actions. 
Table 1. Number of titles accounting for $80 \%$ of use by institute for 2005-06*

\begin{tabular}{lll}
\hline Institutions & $\begin{array}{l}\mathbf{2 0 0 5 - 6} \\
\text { downloads }\end{array}$ & $\begin{array}{l}\text { No of Title } \\
\text { accounting } \\
\text { for 80\% of } \\
\text { use }\end{array}$ \\
\hline $1-\mathrm{U}$ & 120,324 & 316 \\
$2-\mathrm{U}$ & 24,372 & 182 \\
$3-\mathrm{T}$ & 403,348 & 192 \\
$4-\mathrm{U}$ & 142,479 & 245 \\
$5-\mathrm{U}$ & 31,641 & 207 \\
$6-\mathrm{U}$ & 479,991 & 433 \\
$7-\mathrm{U}$ & 79,665 & 280 \\
$8-\mathrm{U}$ & 46,260 & 288 \\
$9-\mathrm{R}$ & 46,230 & 153 \\
$10-\mathrm{U}$ & 140,020 & 326 \\
$11-\mathrm{T}$ & 474,651 & 230 \\
$12-\mathrm{T}$ & 225,040 & 227 \\
$13-\mathrm{T}$ & 24,720 & 123 \\
$14-\mathrm{U}$ & 152,365 & 259 \\
$15-\mathrm{U}$ & 20,650 & 262 \\
$16-\mathrm{U}$ & 51,011 & 223 \\
$17-\mathrm{T}$ & 340,289 & 250 \\
$18-\mathrm{U}$ & 376,973 & 332 \\
$19-\mathrm{U}$ & 247,369 & 311 \\
$20-\mathrm{U}$ & $1,318,957$ & 389 \\
$21-\mathrm{U}$ & 34,140 & 249 \\
$22-\mathrm{U}$ & 752,690 & 409 \\
$23-\mathrm{U}$ & 78,690 & 213 \\
Total & $\mathbf{5 , 6 1 1 , 8 7 5}$ & $\mathbf{6 , 0 9 9}$ \\
\hline U: & &
\end{tabular}

In the tables, U: large multi-subject universities, R: research institutes, S: single subject small universities, ST: multi-subject science $\&$ technology universities

The total publisher list price for the 647 titles was 720,000 USD. This cost was divided between the members but there were two problems. First, the price was still high for some of the members. Second, some of the titles that some members had requested were not included in the list and they wanted them to be added. After considering the comments by all members, Elsevier agreed with our suggestion to offer us two UTLs for the period 2007-2009:

1. UTL1: it included titles that accounted for $67 \%$ of the total use (702 titles), with the total publisher list price of 1,560,000 USD.

2. UTL2: It initially included 384 titles which were chosen by removing 200 titles from the list of journals that accounted for $80 \%$ of usage. However, as the number of titles in this list was low, we removed 17 expensive titles (those with subscription fees more than 5,000 USD) and instead added 65 less expensive titles, so the final number of titles in UTL2 reached 432. Although the 17 removed titles were important ones, we thought that they could be accessed using document delivery services. The total publisher list price for this collection for the consortium was 900,000 USD.

It should be said that out of 58 members of Consiran, 26 members used UTL1, 32 members used UTL2, and two large universities (University of Tehran and Tarbiat 
Modarres Univesity) plus a research centre used FreedomCollection (that includes all of Elsevier journals).

\section{Usage data for the period 2007-2008}

In late 2009, that we had to decide for the period 2010-2012 we needed to investigate the results of the deal for the previous three years. To do that we analyzed the usage data for 2007 and 2008. Table 2 compares the use for years 2005-06 with the use for years 2007-08.

Table 2. Total downloads and percentage of titles accounting for $80 \%$ of use by institute

\begin{tabular}{|c|c|c|c|c|}
\hline Institutions & Usage & $\begin{array}{l}2006 \\
\% \text { of titles } \\
\text { accounting } \\
\text { for } 80 \% \text { of } \\
\text { use }\end{array}$ & Usage & $\begin{array}{l}2008 \\
\% \text { of titles } \\
\text { accounting } \\
\text { for } 80 \% \text { of } \\
\text { use }\end{array}$ \\
\hline $1-\mathrm{U}$ & 120,324 & 23.11 & 183,620 & 29.81 \\
\hline $2-U$ & 24,372 & 13.28 & 135,099 & 30.34 \\
\hline $3-\mathrm{T}$ & 403,348 & 13.99 & 791,229 & 26.78 \\
\hline $4-U$ & 142,479 & 17.56 & 356,743 & 36.03 \\
\hline $5-\mathrm{U}$ & 31,641 & 15.14 & 285,025 & 28.49 \\
\hline $6-U$ & 479,991 & 24.21 & 641,438 & 38.31 \\
\hline 7-U & 79,665 & 20.08 & 263,607 & 32.05 \\
\hline $8-U$ & 46,260 & 21.03 & 46,394 & 34.18 \\
\hline 9-R & 46,230 & 11.04 & 58,582 & 15.52 \\
\hline $10-\mathrm{U}$ & 140,020 & 23.35 & 380,204 & 39.6 \\
\hline $11-\mathrm{T}$ & 474,651 & 9.29 & 737,590 & 30.91 \\
\hline $12-\mathrm{T}$ & 225,040 & 16.55 & 743,059 & 26.61 \\
\hline $13-\mathrm{T}$ & 24,720 & 9 & 336,654 & 26.49 \\
\hline $14-U$ & 152,365 & 18.9 & 456,490 & 31.05 \\
\hline $15-\mathrm{U}$ & 20,650 & 12.68 & 121,800 & 29.77 \\
\hline $16-\mathrm{U}$ & 51,011 & 16.02 & 358,198 & 22.79 \\
\hline $17-\mathrm{T}$ & 340,289 & 17.94 & 864,884 & 28.06 \\
\hline $18-U$ & 376,973 & 21.96 & 806,389 & 38.88 \\
\hline $19-U$ & 247,369 & 22.3 & 674,852 & 28.2 \\
\hline $20-U$ & $1,318,957$ & 27.7 & $1,348,105$ & 40.88 \\
\hline $21-U$ & 34,140 & 18.21 & 165,145 & 30.05 \\
\hline $22-U$ & 752,690 & 29.11 & 179,1654 & 39.74 \\
\hline $23-U$ & 78,690 & 15.58 & 219,149 & 30.62 \\
\hline Total & $5,611,875$ & 18.75 & $11,765,910$ & 31.09 \\
\hline
\end{tabular}

Since all those institutions that had access to 1,394 titles in 2004-2006 opted for UTL1 deal, we could not include UTL2 in our comparison here as it started in 2007.

As Table 2 shows the total number of downloads increased from 5,611,875 in 200506 to $11,765,910$ in 2007-08 (about 209\% increase). Diagrams also show a better distribution of use during 2007-08 compared to 2005-06. The number of journals that accounted for 80 percent of use increased from $18.75 \%$ of the collection in 2005-06 period to $31.09 \%$ in 2007-08 period. Comparison of Figures 2 and 3 with Figure 1 shows that during 2007 and 2008 there were few journals with no use. 
Figure 2. Use of UTL1 collection in 2007

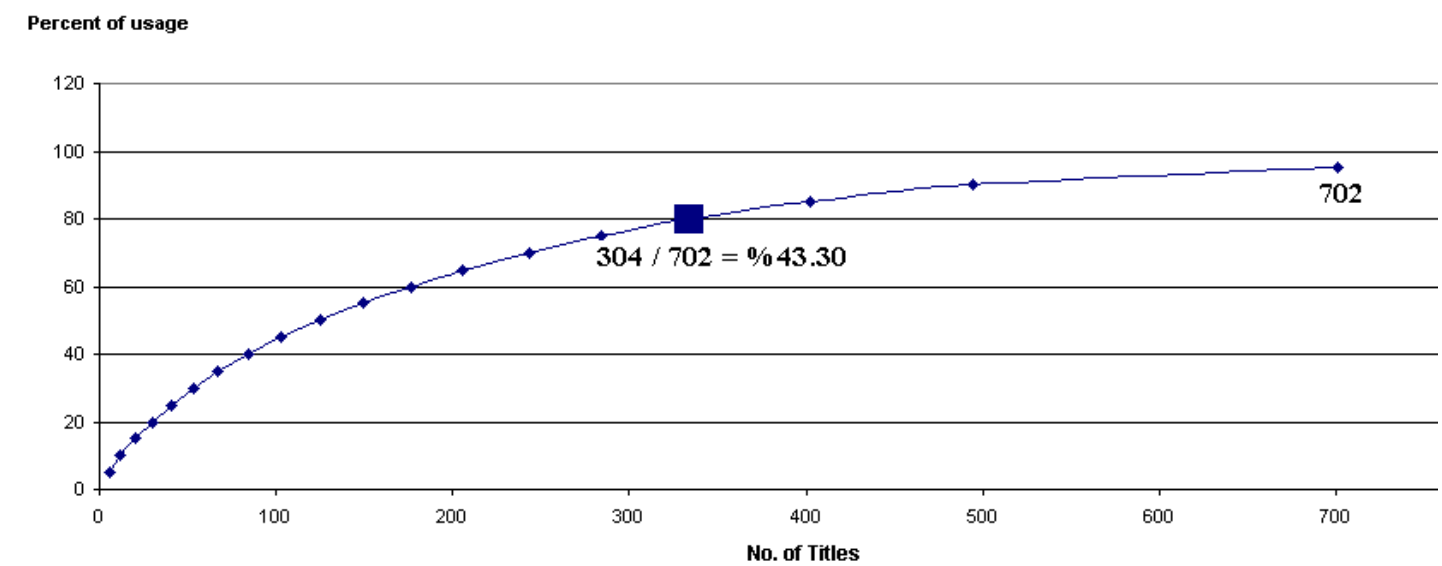

Figure 3. Use of UTL1 collection in 2008

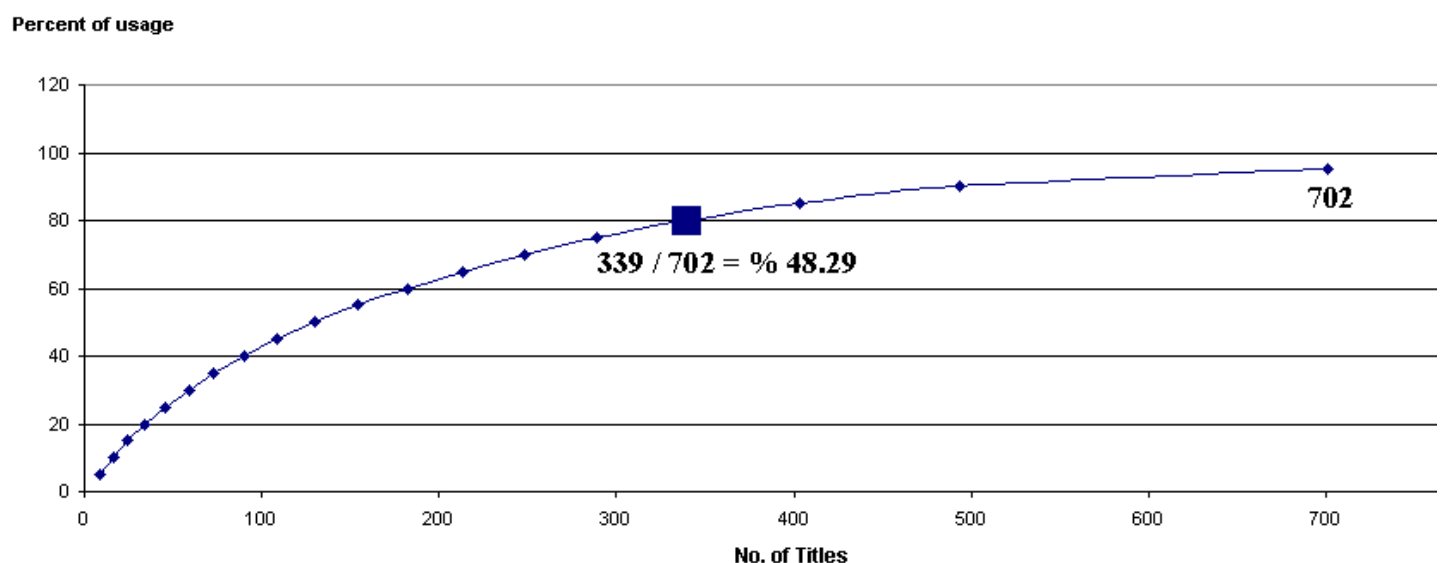

Table 3. Use by UTL1 institutions in 2007 and 2008

\begin{tabular}{lcccccc}
\hline & & $\mathbf{2 0 0 7}$ & & & $\mathbf{2 0 0 8}$ & \\
\hline $\begin{array}{l}\text { Institutio } \\
\text { ns }\end{array}$ & Total use & $\begin{array}{c}\text { \% of titles } \\
\text { accountin } \\
\text { g for 80\% } \\
\text { of use }\end{array}$ & $\begin{array}{c}\text { Cost per } \\
\text { article } \\
\text { (Euro) }\end{array}$ & Total use & $\begin{array}{c}\text { \% of titles } \\
\text { accountin } \\
\text { g for 80\% } \\
\text { of use }\end{array}$ & $\begin{array}{c}\text { Cost per } \\
\text { article } \\
\text { (Euro) }\end{array}$ \\
\hline $24-\mathrm{R}$ & 16,583 & 19.51 & 2.42 & 16,520 & 18.68 & 2.7 \\
$25-\mathrm{U}$ & 197,564 & 31.76 & 0.243 & 181,280 & 35.09 & 0.32 \\
$26-\mathrm{R}$ & 40,923 & 9.4 & 1.5 & 35,461 & 10.41 & 2.01 \\
$27-\mathrm{S}$ & 15,717 & 5.12 & 1.59 & 16,676 & 5.84 & 1.74 \\
$28-\mathrm{U}$ & 38,048 & 29.34 & 0.658 & 50,804 & 29.38 & 0.57 \\
$29-\mathrm{U}$ & 88,914 & 25.35 & 0.911 & 103,264 & 30.67 & 0.85 \\
02-U & 56,638 & 23.64 & 1.04 & 78,463 & 29.52 & 0.87
\end{tabular}




\begin{tabular}{lcccccc} 
03-ST & 378,494 & 26.6 & 0.299 & 412,738 & 27.1 & 0.31 \\
05-U & 159,549 & 23.64 & 0.47 & 125,480 & 30.52 & 0.69 \\
06-U & 291,587 & 34.75 & 0.217 & 349,858 & 37.08 & 0.21 \\
08-U & 27,911 & 33.61 & 1.72 & 18,490 & 30.09 & 3.12 \\
12-ST & 371,942 & 27.49 & 0.456 & 371,121 & 25.96 & 0.53 \\
11-ST & 353,193 & 30.91 & 0.344 & 384,404 & 29.38 & 0.37 \\
13-ST & 167,887 & 26.63 & 0.56 & 168,777 & 25.39 & 0.65 \\
14-U & 237,595 & 30.48 & 0.219 & 218,906 & 29.81 & 0.29 \\
$16-U$ & 207,596 & 18.09 & 0.231 & 150,609 & 25.96 & 0.38 \\
25-U & 171,952 & 34.75 & 0.672 & 184,803 & 35.23 & 0.72 \\
17-T & 423,911 & 27.06 & 0.487 & 438,974 & 27.81 & 0.54 \\
18-U & 398,909 & 38.6 & 0.434 & 405,484 & 37.23 & 0.5 \\
07-U & 117,471 & 32.05 & 0.393 & 146,136 & 30.67 & 0.37 \\
10-U & 203,127 & 38.74 & 0.731 & 177,091 & 38.37 & 0.97 \\
30-U & 51,724 & 28.49 & 0.929 & 70,076 & 28.67 & 0.82 \\
19-U & 367,203 & 21.79 & 0.206 & 305,643 & 32.52 & 0.29 \\
01-U & 111,860 & 39.31 & 1.01 & 129,940 & 37.24 & 1.01 \\
23-U & 106,219 & 28.91 & 0.452 & 112,931 & 30.38 & 0.51 \\
21-U & 76,179 & 27.92 & 0.631 & 88,969 & 29.95 & 0.65 \\
Total & $\mathbf{4 , 6 7 8 , 6 9 6}$ & $\mathbf{2 7 . 4 5}$ & $\mathbf{0 . 7 2}$ & $\mathbf{4 , 7 4 2 , 8 9 8}$ & $\mathbf{2 8 . 8}$ & $\mathbf{0 . 5 6}$ \\
\hline
\end{tabular}

There are two research centers and six small universities in Table 3 that if we exclude them from the data, the percentage of titles that account for 80 percent of use will be $29.85 \%$ in 2007 and $32.25 \%$ in 2008 . It also should be said that out of eight small and medium sized universities, six were engineering and technology universities and the two research centers were active in basic sciences.

Table 4. Use by UTL2 institutions in 2007 and 2008

\begin{tabular}{ccccccc}
\hline Institutio & Total use & $\begin{array}{c}\text { \% of titles } \\
\text { accountin } \\
\text { g for 80\% } \\
\text { of use }\end{array}$ & $\begin{array}{c}\text { Cost per } \\
\text { article, } \\
\text { Euro }\end{array}$ & Total use & $\begin{array}{c}\text { 2008 } \\
\text { \% of titles } \\
\text { accountin } \\
\text { g for 80\% } \\
\text { of use }\end{array}$ & $\begin{array}{c}\text { Cost per } \\
\text { article, } \\
\text { Euro }\end{array}$ \\
\hline $31-\mathrm{U}$ & 19,024 & 21.8 & 0.843 & 26,339 & 24.71 & 0.707 \\
$32-\mathrm{U}$ & 11,414 & 21.34 & 1.43 & 12,467 & 23.55 & 1.52 \\
$33-\mathrm{R}$ & 5,106 & 10.44 & 3.14 & 7,985 & 9.7 & 2.33 \\
$34-\mathrm{U}$ & 6,282 & 16.93 & 3.27 & 8,172 & 18.7 & 2.96 \\
$35-\mathrm{U}$ & 58,260 & 11.13 & 0.275 & 86,883 & 12.93 & 0.214 \\
$36-\mathrm{R}$ & 5,303 & 12.76 & NTPA & 8,302 & 14.31 & NTPA \\
$37-\mathrm{U}$ & 22,318 & 28.77 & 0.719 & 51,314 & 21.01 & 0.362 \\
$38-\mathrm{R}$ & 22,557 & 9.04 & 0.711 & 22,190 & 10.85 & 0.839 \\
\hline
\end{tabular}




\begin{tabular}{ccccccc}
\hline 39-R & 0 & 0 & 0 & 9,166 & 12.24 & NTPA \\
$40-\mathrm{R}$ & 15,290 & 6.26 & NTPA & 14,887 & 4.15 & NTPA \\
$41-\mathrm{U}$ & 21,773 & 20.88 & 0.737 & 35,309 & 24.01 & 0.527 \\
$42-\mathrm{U}$ & 17,205 & 21.8 & 0.933 & 20,809 & 26.32 & 0.895 \\
$43-\mathrm{U}$ & 22,263 & 21.34 & 0.721 & 23,771 & 26.32 & 0.783 \\
$44-\mathrm{U}$ & 66,393 & 5.56 & 0.241 & 13,072 & 22.63 & 1.42 \\
$45-\mathrm{R}$ & 7,376 & 12.06 & 2.17 & 9,494 & 13.39 & 1.96 \\
$46-\mathrm{U}$ & 3,036 & 12.52 & 5.38 & 4,356 & 14.31 & 4.35 \\
$47-\mathrm{U}$ & 202,399 & 23.66 & 0.08 & 12,932 & 19.63 & 1.46 \\
$48-\mathrm{ST}$ & 32,630 & 20.88 & 0.896 & 46,772 & 22.86 & 0.694 \\
$49-\mathrm{U}$ & 15,880 & 16.7 & 1.01 & 22,092 & 22.17 & 0.843 \\
$50-\mathrm{U}$ & 77,681 & 15.54 & 0.206 & 57,111 & 23.32 & 0.326 \\
$51-\mathrm{ST}$ & 3,153 & 15.31 & 5.09 & 7,200 & 16.85 & 2.58 \\
$52-\mathrm{U}$ & 4,444 & 20.64 & 3.67 & 5,396 & 20.78 & 3.51 \\
$53-\mathrm{U}$ & 11,294 & 12.29 & NTPA & 16,182 & 20.55 & NTPA \\
$54-\mathrm{U}$ & 23,883 & 16 & 0.672 & 26,081 & 17.55 & 0.714 \\
$55-\mathrm{U}$ & 10,134 & 18.56 & 1.58 & 10,201 & 22.86 & 1.82 \\
$56-\mathrm{U}$ & 16,322 & 22.5 & 0.983 & 23,992 & 30.71 & 0.776 \\
$57-\mathrm{U}$ & 33,419 & 23.89 & 0.48 & 54,760 & 26.55 & 0.34 \\
$58-\mathrm{U}$ & 58,349 & 26.91 & 0.403 & 55,776 & 28.17 & 0.49 \\
$59-\mathrm{U}$ & 9,411 & 21.34 & 1.73 & 15,347 & 23.32 & 1.25 \\
$60-\mathrm{U}$ & 18,635 & 22.27 & NTPA & 39,706 & 22.4 & NTPA \\
$61-\mathrm{U}$ & 10,327 & 27.61 & 6.07 & 35,466 & 29.33 & 1.96 \\
$62-\mathrm{S}$ & 227 & 3.48 & NTPA & NUA & NUA & NUA \\
Total & 831,788 & 16.88 & 1.35 & 783,530 & 19.56 & 1.11 \\
\hline NTA & & 0.35 & &
\end{tabular}

NTPA: no title price available; NUA: no usage data available

There are twelve research centers and six small universities in Table 4 that if we exclude them from the data, the percentage of titles that account for 80 percent of use during 2007 and 2008 will be $19.62 \%$ and $22.92 \%$ respectively. Out or eight small and medium sized universities, six were engineering and technology universities and the two research centers were active in basic sciences.

We can conclude from Tables $3 \& 4$ that the average number of titles accounting for $80 \%$ of use in engineering universities was high and close to that of large universities. The figure for engineering universities in UTL2 list was $18.09 \%$ in 2007 and $19.65 \%$ in 2008, and for universities in UTL1 it was $27.78 \%$ in 2007 and $27.12 \%$ in 2008.

A closer look at the usage in 2007 and 2008 reveals that the use is distributed evenly which in turn might be an indication that the journals were selected rightly. However, unlike UTL1 collection in which the use by individual institutions matches the total use, in UTL2 (Figures $4 \& 5$ ) the use by individual institutions does not reflect the total use. Figures 4 and 5 show that the 432 titles were used fairly well and that 80/20 ratio changed to $80 / 50$. However, the investigation of use by individual institutions shows that this type of deal were not efficient at institutional level. 


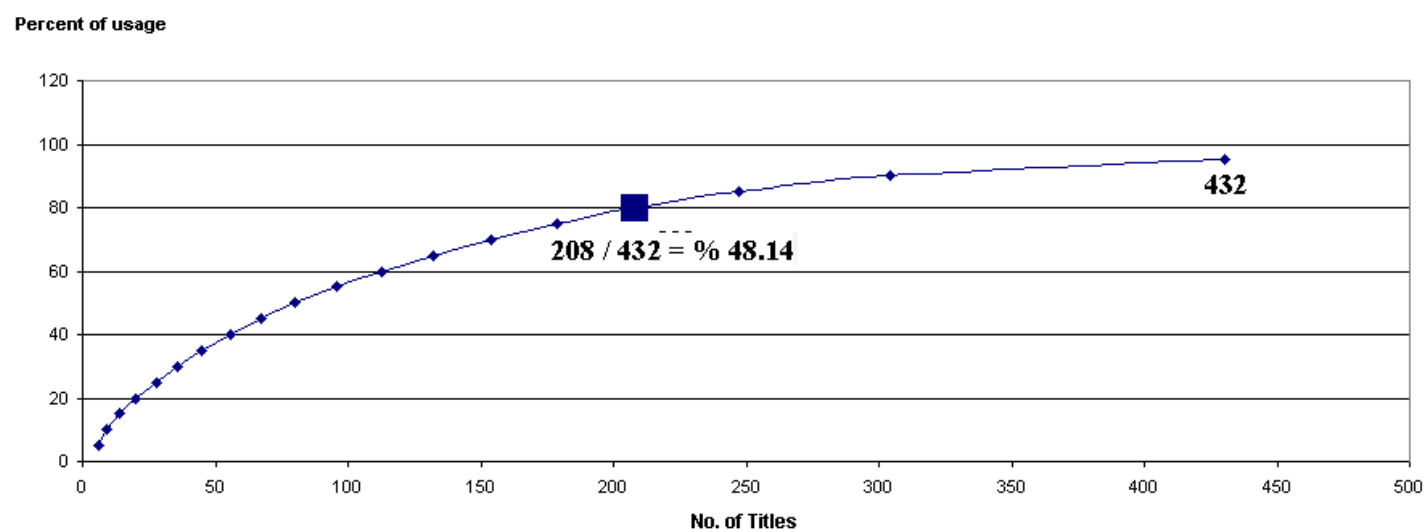

Figure 5. Use of UTL2 collection in 2008

Percent of usage

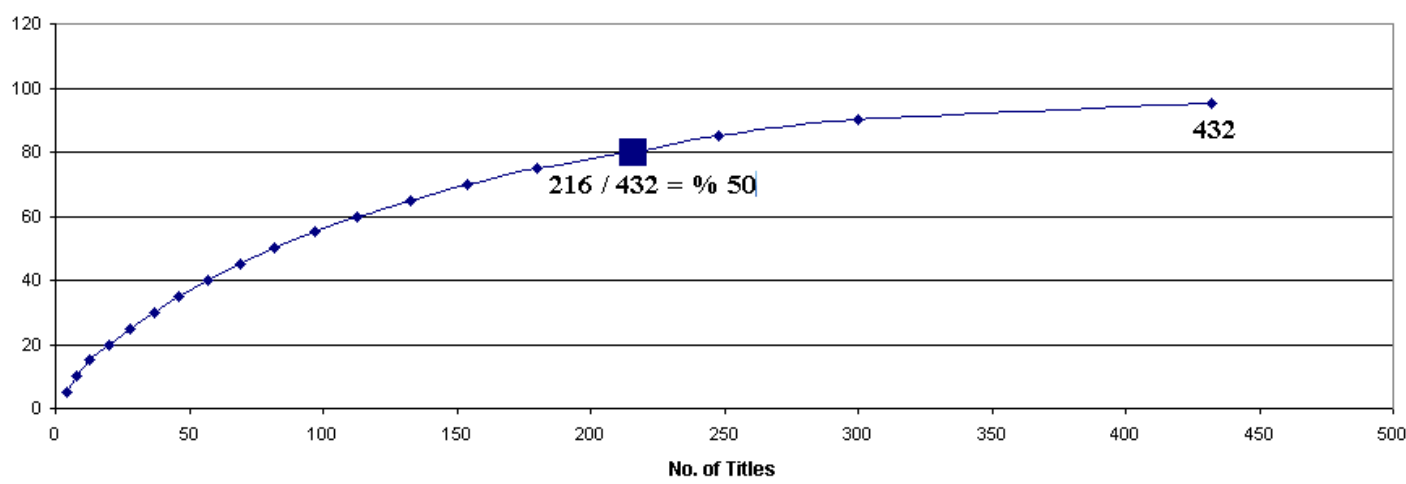

The access to Freedom Collection covered 1,952 titles. The three institutions accounted for $30.86 \%$ of total use of the consortium in 2007 and 2008 (see Table 5).

Table 5. Use of Freedom Collection by three institutions

\begin{tabular}{lllllll}
\hline & & $\begin{array}{l}\text { \% of titles } \\
\text { accounting } \\
\text { for 80\% of } \\
\text { use }\end{array}$ & $\begin{array}{l}\text { Cost per } \\
\text { article }\end{array}$ & Total use & Total use & $\begin{array}{l}\text { Cost per } \\
\text { article }\end{array}$ \\
09-R & 36,883 & 9.27 & 3.5 & 36,933 & 7.35 & 4.05 \\
$20-\mathrm{U}$ & 891,156 & 26.22 & 0.329 & 808,078 & 25.14 & 0.399 \\
$22-\mathrm{U}$ & $1,125,082$ & 24.23 & 0.435 & $1,061,667$ & 22.29 & 0.505 \\
\hline
\end{tabular}

\section{Discussions and conclusions}

The analysis of usage data and calculation of cost per article showed that the decision for dividing the institutions into the two groups of UTL1 and UTL2 was relatively a wise decision. However, it is clear that for the next three-year period (2010-2012) we should have more options and it would be a wiser decision to break the institutions 
into probably four groups, especially those currently subscribed to UTL2. For UTL1 universities, we could still modify the journal list to better reflect their real needs.

The usage data also show a considerable increase in the number of downloads. This should not be surprising because during the recent years scientific productivity in Iran has boosted. For example, the number of articles published by Iranian authors in ISI ranked journals has increased from 1,955 articles in 2001 to about 16,000 articles in 2008.

We faced a few challenges in analyzing usage data obtained from the publisher. Some of the problems that should be thought about are:

Systematic download by students: many users in Iran are sceptical about the continuity of access to online contents. Therefore, when they have access they might try to download the content for the future use. In the past, we have had cases when we had to close the access of a specific IP or user due to systematic download.

Systematic download by vendors: this one might sound pessimistic and it may not be true. However, we had to consider all possibilities. The vendors and dealers provide universities with the password to enter the publishers' sites. To make the deals sound more economic they might attempt systematic downloads to show that the usage data are high. Other authors ${ }^{12}$ have also mentioned this concern. In the case of some journals, the number of downloads sounded unreasonably high, e.g. 32,000 article downloads in a year. We tried to compare the online use data with the use of print copies (pre-1998 volumes) to have a better estimation of use. We realised that while it is norm to use re-shelving data as a measure of print copy use, in Iran the number of photocopies made by users is a more reliable measure of print copy use, as Iranian users tend to photocopy articles and read them in their office at their convenience instead of reading the journal in the library.

Inappropriate use: investigation of publisher's statistics showed that the number of abstracts viewed was far smaller than the number of full-text downloads. This could be an indication that users tend to read the full-text instead of abstracts and that abstracts play an insignificant role in users' information-seeking behaviour. But it could also be an indication that users download the articles without even really needing them or reading them. To investigate this issue further, observations and interviews were later carried out at different computer sites and it was confirmed that part of the use is inappropriate. Some users maintained that they tend to download the full-text as soon as they have a chance because due to the slow speed of Internet connection and lack of trust on the future access they do not want to waste their time to look for the same article again in the future and that they prefer to have it in their personal archive.

To conclude, moving toward the provision of extensive access to a wider range of journals considering cost-benefit analysis should be the main goal of Consiran. Adopting a National Site License model, such as NESLI in UK is also something that should be considered. Providing access to a larger number of journals for a larger number of universities might not be feasible and for the next three-year period we might have to break the universities into three or four groups. This will help us have better selected sets of journals especially for smaller universities and specialized research centers. We also believe that due to the aforementioned problems with usage data, locally collecting usage data, rather than relying on the usage data provided by vendors and publishers, is an option that is worth considering. The study also confirms that, as Bucknell ${ }^{13}$ said, we can use simple statistical analysis to calculate performance metrics for Big Deals and decide about library e-journal collections. 


\section{Notes}

1. Scott Gillies and Tony Horava, "Developing a model license: a Canadian consortium's experience," in E-journals Access and Management, ed. Wayne Jones, (New York: Rutledge. 2008), 91-117.

2. Joy Kirchner, "Current challenges in licensing negotiations: an academic library perspective", in E-journals Access and Management, ed. Wayne Jones, (New York: Rutledge. 2008), 67-89.

3. Kenneth Frazier, "The librarians' dilemma: Contemplating the costs of the 'big deal," D-Lib magazine 7, no. 3 (March 2001), http://www.dlib.org/dlib/march01/frazier/03frazier.html (accessed November 20, 2009).

4. Rollo Turner, "National site licensing and consortia purchasing," Library consortium management: an international journal 1 no.1/2 (1999): 33-40.

5. Margaret J. Sylvia, "Citation analysis as an unobtrusive method for journal collection evaluation using psychology student research bibliographies," Collection Building 17, no. 1 (1998): 20-28; Sherri Edwards, "Citation analysis as a collection development tool: a bibliometric study of polymer science theses and dissertations," Serials Review 25 no.1 (1999): 11-20.

6. Paola Gargiullo, "Electronic journals and users: the CIBER experience in Italy," Serials 16 (2003): 293-298; Hamid R. Jamali, David Nicholas and Paul Huntington, "The use and users of scholarly e-journals: a review of log analysis studies," Aslib Proceedings 57 (2005): 554-571; David Nicholas, Paul Huntington and Hamid R. Jamali, "What deep log analysis tells us about the impact of big deals: case study OhioLINK," Journal of Documentation 62 (2006): 482-508. 
7. Yas Tonta and Yurdagul Ünal, "Consortial use of electronic journals in Turkish universities," in Open Scholarship: Authority, Community and Sustainability in the Age of Web 2.0: Proceedings of the 12th International Conference on Electronic Publishing, Toronto, June 25-27, 2008. (pp. 203-216). Toronto, Canada: International Conference on Electronic Publishing (ELPUB).

8. Tonta and Ünal, "Consortial use of ...".

9. Jeffrey N. Gatten and Tom Sanville, "An orderly retreat from the big deal: is it possible for consortia?” D-Lib Magazine 10, no. 10 (October 2004) http://www.dlib.org/dlib/october04/gatten/10gatten.html (accessed November 20, 2009).

10. Cherifa Boukacem-Zeghmouri and Joachim Schöpfel, "On the usage of e-journals in French Universities," Serials 21, no. 2: 121-126.

11. Paul Evans and John Peters, "Analysis of the dispersal of use for journals in Emerald Management Xtra (EMX),” Interlending \& Document Supply 33, no. 3 (2005): 155-157.

12. Joanna Duy and Liwen Vaughan, "Usage data for electronic resources: A comparison between locally collected and vendor-provided statistics," Journal of Academic Librarianship 29, no. 1 (2003): 17.

13. Terry Bucknell, "Usage statistics for Big Deals: supporting library decisionmaking," Learned Publishing 21, no.3 (2008): 193-199. 